\title{
Procedimientos de restauración del sentido ordinario de la realidad: un estudio de las secuencias de revelación de las bromas de cámara oculta
}

\author{
A. Javier Izquierdo* \\ UNED \\ jizquier@poli.uned.es
}

RESUMEN

Concebidas como objetos de comunicación pública, las bromas de cámara oculta (BCOs) constituyen una variante documental de las bromas ordinarias. Frente a los clásicos experimentos de ruptura garfinkelianos, las BCOs ofrecen asimismo una forma natural de experimentación etnometodológica. Se presentan aquí algunos resultados del análisis de una muestra de cuarenta y nueve secuencias de revelación (SRs) de BCOs. Estos pequeños clips (de entre cinco y cincuenta segundos de duración) permiten describir gran cantidad de detalles audiovisuales característicos del singular trabajo interaccional, finamente coordinado, que han de llevar a cabo los actores, ganchos y víctimas de una BCO para «poner punto final» a una situación social artificialmente fabricada. Mi estudio se centra en una serie de curiosas relevancias prácticas del trabajo de revelación (ofrecimiento) y despertar (aceptación/rechazo) puestas de manifiesto y tematizadas internamente por el propio trabajo de producción social in vivo de los agentes enfangados en la situación de BCO. Particularmente interesante es el descubrimiento de que las justificaciones académicas constitutivas de la secuencia de revelación de los experimentos de ruptura etnometodológicas son sustituidas aquí por un singular tópico de conversación mundana (la localización especial de dispositivos de registro y transmisión audiovisual).

Palabras clave: Etnometodología, Sociología del Humor, Videosociología.

\footnotetext{
* Agradezco a Carlos Moya sus comentarios, tan inefables como certeros, a una primera versión de este trabajo; y le agradezco también a Fernando García Selgas sus útiles observaciones críticas a borrador posterior. La asistencia de Beatriz Hernández, técnico del Departamento de Medios Técnicos (Vídeo y Audio Digital) del Centro de Diseño y Producción de Medios Audiovisuales (CEMAV) de la Universidad Nacional de Educación a Distancia, en las tareas de digitalización de vídeo, ha sido esencial para poder llevar a cabo esta investigación. Gracias también a Victoria Lucio y al personal de la Mediateca de la UNED por su infinita paciencia para con mis rarezas. Agradezco, finalmente, al Grupo de Exploración Proyectual de la Escuela Técnica Superior de Arquitectura de Madrid (Andrés Perea, Paula Montoya, Rafael Torrelo, Izaskun Chinchilla y Andrés Jaque), por haberme brindado la oportunidad de exponer en público por primera vez algunos de los resultados de esta investigación.
} 
¿Quiénes podrían ser estos hombres?, ¿qué autoridad representaban? K. vivía en un Estado de Derecho, donde reinaba una paz general y todas las leyes se mantenían vigentes. ¿Quién se atrevía a asaltarle en su propio domicilio? Tendía siempre a tomárselo todo de la mejor manera posible, a ponerse en lo peor sólo cuando lo peor estaba ocurriendo, a no tomar precauciones para el futuro, aunque todo fuesen amenazas. Pero le chocaba que ese criterio no pareciese el más adecuado en este caso; la verdad es que uno podía tomárselo todo como si se tratase de una broma, una broma pesada que, por razones desconocidas (tal vez porque era su treinta cumpleaños), habian organizado sus compañeros del banco; no dejaba de ser posible; puede que bastase con hallar el modo de reírse ante las propias narices de los guardias, y ellos también se reirían; quizá fuesen mozos contratados en cualquier esquina; no dejaban de parecerse a ellos, sin embargo esta vez, ya desde la primera aparición del guardia Franz, estaba decidido a no renunciar ni a la más mínima ventaja que pudiese tener sobre aquella gente. En verdad corría el pequeño riesgo de que después dijesen de él que no había sabido aguantar una broma, pero recordaba muy bien -aunque no fuese con él eso de escarmentar de la experienciaalgunos casos, insignificantes en sí mismos, en los cuales, habiendo hecho oídos sordos a las advertencias de sus amigos, había obrado intencional de un modo imprudente, sin tener en cuenta las posibles consecuencias de sus actos, y al final había tenido que pagar dolorosamente por ello. Aquello no podía volver a ocurrir, por lo menos no en este caso; si se trataba de una comedia esta vez la seguiría hasta el final'.

\section{INTRODUCCIÓN: CÓMO FINALIZAN LOS EXPERIMENTOS ETNOMETODOLÓGICOS}

Los llamados «experimentos de ruptura» (breaching experiments; en adelante, ERs) o «técnicas problematizadoras» (troublemakers) empleados por los etnometodólogos son parientes investigadores más o menos cercanos de esa figura familiar de la vida ordinaria: la broma².

\footnotetext{
1 Kafka, El proceso, citado en Harvey Sacks, «An Initial Investigation of the Usability of Conversational Data for Doing Sociology», en D. Sudnow (ed.), Studies in Social Interaction, Nueva York, The Free Press, 1972, 31-74, pp. 48-49.

2 «Décadas después de la publicación de Studies [Studies in Ethnomethodology, 1967], "Ios experimentos de Garfinkel” se habían convertido en una especie de institución dentro de los manuales y las clases de introducción a la sociología. Los lectores que fueran estudiantes en aquella época seguramente recordarán las múltiples versiones que existían de esos ejercicios, entre las cuales se contaban comportamientos extraños en los ascensores, extravagantes gambitos conversacionales, muestras excesivas de buenos modales en la mesa, peticiones repetidas de aclaración en conversaciones ordinarias, y cosas por el estilo. Cuando son simplemente mencionados, o se los lleva a cabo de forma aislada, estos ejercicios pueden parecer poco más que chistes tontos o bromas de cámara oculta [Candid Camera episodes], especialmente si se omite una explicación sobre la concepción original que de ellos tenía Garfinkel como "demostraciones pedagógicas de conceptos sociológicos básicos" o sobre la medida en que su diseño estaba inspirado por el esquema conceptual desarrollado por Alfred Schutz en el que a la racionalidad "científica" se oponía de forma sistemática la racionalidad "de sentido común"» (M. Lynch y W. Sharrock, «Editor's Introduction», en Lynch y Sharrock, eds., Harold Garfinkel. Vol. 1, Londres, Sage, 2003, VII-XLVI, p. XV).
} 
El propósito con el que se diseñaron originalmente estos experimentos era el de contribuir a «revelar» o «hacer visible» un complejísimo, finísimo y sutilísimo tejido de presupuestos normativos dados por supuestos (taken for granted) y expectativas morales de fondo (background expectancies) que, en circunstancias normales o no problemáticas, permanece en estado invisible, o más precisamente que, aunque es percibido, nos pasa al mismo tiempo inadvertido (seen but unnoticed), en razón de su carácter a la vez masivamente omnipresente, implícito y rutinario. Es sobre este tejido normativo implícito, con los hilos de esta trama situacional de presupuestos y expectativas tácitas, con los que dibujamos nuestras actividades más ordinarias, luego más ineludibles. Muy especialmente son éstos los materiales de los que nos servimos para ordenar, de manera cooperativa, nuestras conversaciones, dotándoles internamente de coherencia formal y sentido localmente inteligible.

De entre los varios diseños experimentales descritos en los Studies in Ethnomethodology de Garfinkel, hay dos que guardan un parecido especialmente estrecho con las bromas de la vida cotidiana ${ }^{3}$. Uno de ellos consiste en un ejercicio de clase en el que el profesor pide a los estudiantes, como tarea para casa, que, durante un período de tiempo entre quince minutos y una hora, se dediquen a observar el comportamiento «familiar» de sus padres y hermanos tal como lo haría un antropólogo extraterrestre y relaten luego sus observaciones «etológicas» en un informe escrito. Una variante particularmente dificultosa de este ejercicio consiste en que los alumnos, durante un período equivalente, se comporten en su propio hogar con la cortesía y la deferencia propias de un huésped y luego describan sus impresiones. El objetivo del experimento es hacer evidente a los estudiantes el carácter omnirrelevante de la «familiaridad» con personas y objetos como fundamento de la acción ordinaria. Por su parte, el segundo tipo de ERs que asemejan a bromas tiene como propósito ilustrar a los estudiantes sobre uno de los atributos distintivos de la racionalidad científica como contrapuesta a la racionalidad ordinaria: la búsqueda de la claridad como un valor en sí mismo 4 . Para tal fin el profesor indicaba a sus estudiantes (los «experimentadores») que, en mitad de una conversación con algún amigo o familiar a mano (el «sujeto»), y sin indicar de ningún modo que lo que van a o acaban de hacer es algo raro o inusual, debían solicitar de sus interlocutores que "clarificasen» el sentido de las expresiones «de sentido común» que éstos acababan de emplear ${ }^{5}$.

3 Cf. H. Garfinkel, «Studies of the Routine Grounds of Everyday Activities», en Garfinkel, Studies in Ethnomethodology [1967], Londres, Polity, 1984, 35-75.

4 Cf. H. Garfinkel, «The Rational Properties of Scientific and Common Sense Activities», en Garfinkel, Studies in Ethnomethodology [1967], Londres, Polity, 1984, 262-283.

5 Véase el Apéndice para extractos de los informes en los que los alumnos referían los resultados obtenidos en estos experimentos. 
En su meta-informe original, Garfinkel despacha con un análisis muy somero el tema del «cierre» de los experimentos, tal como lo refieren los estudiantes en sus informes escritos. Los procedimientos cooperativos de «desvelamiento» no se examinan en detalle: simplemente, tras la enumeración de los síntomas típicos de las víctimas, se alude de pasada a la imposibilidad de «restaurar la situación» por parte de los experimentadores. De una parte, la justificación estándar de los experimentadores eludía el empleo de la palabra «broma», sustituyéndola por «experimento» o «ejercicio» impuesto por el «profesor de sociología». Frente a este tipo de justificación la respuesta típica de las víctimas consistía en una aceptación parcial, matizada por una queja: «Vale, pero ¿por qué a mí?».

«Denegación, cabreo, embarazo agudo, disimulo y sobre todo incertidumbres referidas a estos estados, así como incertidumbres de miedo, espera y enfado fueron también resultados típicos... De manera característica, los experimentadores fueron incapaces de restaurar la situación. Los sujetos sólo aceptaron parcialmente la explicación del experimentador de que lo había hecho "como un experimento para un curso de sociología". Una queja frecuentemente formulada por las víctimas era del tipo "Vale, muy bien, era un experimento, ¿pero por qué has tenido que escogerme a mí"” 6 .

El estudio sobre las SRs de las BCOs que presento aquí pretende recuperar los detalles vividos audiovisualmente preservables de algunos de los fenómenos aludidos por Garfinkel en este párrafo. ¿Cómo hacen el actor y, en su caso, el gancho para mantener la tensión entre incertidumbre e información? ¿Durante cuánto tiempo les es materialmente posible mantenerla? ¿Mediante qué procedimientos (dramáticos o de otro tipo) es posible «tensar aún más» esa tensión? ¿Cómo hace la víctima para «caer a tierra»? ¿Qué palabras o frases, pronunciadas o escuchadas justamente de qué manera, le hacen «caer de golpe»? ¿O bien qué gestos, miradas y movimientos, exactamente qué gestos, miradas y movimientos, tanto suyos como de los actores y ganchos, le depositan gentilmente en el suelo de la «realidad»? ¿Cuál es el timing exacto que ha de seguir, o más bien «crear», el actor para introducir esa pausa aparentemente inocua que acaba detonando el despertar-se de la víctima? ¿Cuál el momento justo para introducir o cerrar la «frase estratégica» promovida por el o los guionistas de la broma como «despertador infalible»? ¿Qué miradas y movimientos le «hacen» a la víctima «explotar» de alivio o «deshacerse» en llanto? ¿Qué contingencias extrañas y acontecimientos imprevistos co-producidos por todos los participantes en la escena ocasionan una distensión brusca, un estiramiento prolongado hasta el límite del disparate y lo desternillante, o bien una ruptura irreversible del hilo invisible que

6 Garfinkel, «Routine Grounds», op. cit., 73. 
mantiene la continuidad de la interacción? ¿Cuáles los detalles mínimos, concretos, precisos con los que se consigue "dar en el blanco» y que marcan de hecho la diferencia (abismal) de calidad entre un desenlace previsible y una sorpresa mayúscula? ¿Cómo hace el actor para «abrir espacio» en el curso vertiginoso de la escena final para ese «silencio» imposiblemente prolongado que produce efectos cómico-dramáticos «máximos», justamente porque permite ocultar el hecho de que quien lo sostiene está esperando la ocurrencia inminente del «hachazo final»? ¿En qué momento exacto se cruza la barrera entre lo aceptable y lo enojoso, entre la broma «inteligente» y la broma «pesada»? En suma, ¿cómo hacen exactamente experimentador y sujeto para retornar juntos a la realidad?

\section{RECICLAJE DE «TELE-BASURA» Y METODOLOGÍA SOCIOLÓGICA: EL CASO DE LAS BROMAS DE CÁMARA OCULTA (BCOs)}

Las técnicas que, en un sentido que, creo, va más a allá de la mera analogía, podemos calificar de «ecológico-informacionales», orientadas al reciclaje de material fílmico de derribo o «desechos audiovisuales», disfrutan en la actualidad de múltiples usos. Su empleo, tan masivo como característico del documental, género cinematográfico académicamente respetable donde los haya ${ }^{7}$, puede también detectarse, desde tiempos más recientes, en el nivel cero de la producción televisiva, constituido por programas de «zapeo» (como Zap, zap... zapping, el formato original emitido por Canal + y sus distintas secuelas, como La batidora, en Antena 3), en los que los propios profesionales de televisión seleccionan los fragmentos más «divertidos» emitidos a lo largo de la semana por las distintas estaciones de televisión, tanto nacionales como locales o de pago.

Las técnicas de reciclaje de material audiovisual de desecho son también las herramientas de producción esenciales de los concursos de vídeos familiares (el pionero Vídeos de familia, en Antena 3, y sus sucesores más recientes, como Olé tus vídeos, en la misma cadena), así como de los programas de «imágenes de impacto» (como Alta Tensión y Hora Punta, emitidos por TVE-1; o Impacto TV, en Antena 3), que se nutren de la fortuna del videoaficionado y del oportunismo del «periodista de investigación ${ }^{8}$ tanto como del funcio-

\footnotetext{
7 Véase B. Nichols, An Introduction to Documentary, Bloomington (IN), Indiana University Press, 2001. Para una introducción a la historia del sub-género académicamente aún más respetable del documental etnográfico, vid. E. de Brigard, «Historia del cine etnográfico» [1975], en E. Ardévol y L. Pérez Tolón (eds.), Imagen y cultura. Perspectivas del cine etnográfico, Granada, Diputación Provincial de Granada, 1995, 31-73.

8 Desde el momento que se decide a portar una «cámara oculta», el periodista se comporta, necesariamente, como actor. Para un ejemplo extremo de este método de investigación, véase el trabajo clásico del periodista alemán Günter Walraff (Cabeza de turco. Abajo del todo, Barcelona, Anagrama, 1987) y el más reciente de A. Salas, Diario de un skin, Madrid, Temas de Hoy, 2002. Esta modalidad híbrida de «periodismo de investigación», basada en el empleo del recurso de la cámara oculta como fuente casi exclusiva de información, se ha convertido en la seña de identidad distintiva de algunas jóvenes productoras
} 
namiento continuo de la multitud creciente de dispositivos de vídeovigilancia policiales y corporativos (así, los sistemas basados en un conjunto de cámaras enlazadas como un Circuito Cerrado de Televisión o CCTV) o del peculiar trabajo fílmico, esencialmente burocrático, de los camarógrafos profesionales al servicio de cuerpos de seguridad estatales. (Por cierto que lo mismo tiende a suceder cada vez con mayor frecuencia en el caso de los propios programas informativos «serios».)

Al lado de avenidas vecinas de indagación sistemática sobre las capacidades de conocimiento científicas que ofrecen los placeres sensuales del trabajo espectatorial aplicados a la fenomenología de las técnicas de visibilización cinematográficas y videográficas - como las notables investigaciones emprendidas en el marco de las actividades de asistencia comunitaria y promoción identitaria de los movimientos anti-sida $-{ }^{9}$, una de las más relevantes muestras estratégicas de las potencialidades teóricas inherentes a la construcción de materiales audiovisuales «de derribo» (e.g., secuencias de telefilmes de «serie b») como datos empíricos propios, en el sentido de naturales de y, por tanto, naturalmente apropiados para la investigación social, la ofrece el estudio de Jeffrey Shandler sobre el doble estatuto cultural del material de filmación obtenido por las tropas aliadas en los campos de concentración nazis, a la vez prolegómeno de la era televisiva y nutriente vital de su expansión tecno-económica, y procedimiento evidenciario modelo para la percepción cultural y persecución institucional de nuevos «crímenes contra la humanidad»10.

Una llamativa «variante cívica» de los procedimientos de trabajo fílmico más o menos «naturales» - los dos polos de cuyo espectro serían el periodismo de investigación con cámara oculta y los sistemas de videovigilancia organizacional- es el «videoactivismo», esto es, el empleo de cámaras de vídeo como «armas contra la violencia», tal como ha sido puesto en práctica (entre otros) por los numerosos «proyectos» de un grupo de ONGs de ámbito internacional que se dedican a prestar cámaras de vídeo a asociaciones por la defensa de derechos humanos, y a entrenar a sus miembros en el manejo de la cámara con

\footnotetext{
de televisión surgidas en España a principios del nuevo siglo, como EL MUNDO TV o EM 3 Entertainment, creadoras de una serie de formatos de programa de corte similar centrados en la exposición y el comentario de materiales audiovisuales obtenidos mediante la aplicación de este procedimiento (Investigación TV, A corazón abierto, Al descubierto, emitidos por distintas cadenas de televisión: Telemadrid, Tele 5, Antena 3).

9 Véase A. Juhasz, AIDS TV. Identity Community and Alternative Video, Londres, Duke University Press, 1995. Por supuesto, la pornografía, en particular en sus variantes filmográfica y videográfica, es otra de esas áreas de producción documental que pueden calificarse como «minas de oro» para la investigación etnometodológica sobre el carácter naturalmente organizado y naturalmente analizable de la acción práctica. Véanse L. Williams, Hard Core. Power, Pleasure, and the «Frenzy of the Visible», Berkeley y Los Ángeles (CA), University of California Press, 1999; C. Hansen, C. Needham y B. Nichols, «Pornografía, etnografía y los discursos del poder» [1991], en Nichols, La representación de la realidad. Cuestiones y conceptos sobre el cine documental, Barcelona, Paidós, 1997, 257-287.
}

10 J. Shandler, While America Watches. Televising the Holocaust, Oxford, Oxford University Press, 1999. 
objeto de obtener documentos audiovisuales que sirvan para dar a conocer y defender su causa ante la opinión pública y los tribunales. La organización pionera del «videoactivismo global», de nombre Witness (Testigo), tiene su sede en la ciudad de Nueva York ${ }^{11}$. Empleando una metodología inspirada en actividades espontáneas (e.g., la filmación casual del «encuentro» de Rodney King con los agentes del Departamento de Policía de Los Ángeles), esta y otras ONGs han producido en colaboración una serie de documentales, ampliamente difundidos en las televisiones de todo el mundo, sobre problemas tan variados como la violencia paraestatal contra movimientos por los derechos indígenas en Centroamérica, el uso sistemático de las violaciones como arma en los conflictos bélicos africano-occidentales, las condiciones de vida de los internos en establecimientos psiquiátricos, etc.

Junto con hacer cada vez más palpable y evidente la vocación reflexiva original del trabajo de producción de imágenes en soporte videográfico y cinematográfico, las técnicas de «cámara oculta» $\mathrm{u}$ «objetivo indiscreto» 12 han sido la avanzadilla de la creciente gama de formatos televisivos producidos mediante el «reciclaje de imágenes de desecho». Emparentados con otros géneros, como los montajes de «tomas falsas» o de materiales filmados sobre el desarrollo de los rodajes televisivos y cinematográficos (los Cómo se hizo/rodó... [Making Off...]), los programas de cámara oculta ofrecen una herramienta incomparable al trabajo ordinario de descubrimiento (científico) de las estructuras prácticas de la acción social, por cuanto orientan a los espectadores al examen de las estructuras sociales en y en tanto que los detalles in vivo e in situ que hacen públicamente reconocible la realidad de algo así como un orden social.

«El término actividades ordinarias organizadas de modo natural [naturally organized ordinary activities] pone el acento sobre el hecho de que las actividades objeto de investigación son ordinarias, están organizadas, y esa organización es natural en el sentido de que forma parte de la actividad misma, y la convierte en lo que es. Estas actividades son reflexivas, auto-organizadas, enteramente organizadas in situ, localmente. Esta organización no tiene un origen divino, ni tampoco está determinada por las propiedades innatas del espíritu, y su sentido queda más bien ofuscado cuando uno se refiere a ella como comportamiento socializado o aprendido —como si esos términos explicasen lo que efectivamente se llevó a cabo, con todos sus detalles, y, por ende, aquello que suponemos que sus participantes conocían o habían aprendido»13.

11 Véase la información difundida a través de su página web: www.witness.org.

12 Éste era el nombre de un programa emitido a finales de la década de 1970 por Televisión Española en el que el guionista y director de cine sevillano Manuel Summers (1935-1993), antiguo alumno de la Escuela Oficial de Cinematografía, comenzó a aplicar las técnicas de cámara oculta que emplearía posteriormente en una serie de películas realizadas en la primera mitad de la década de 1980.

13 E. Livingston, Making Sense of Ethnomethodology, Londres, Routledge, 1987, 10. 
Así, por ejemplo, en los fragmentos de «tomas falsas», los detalles sonoros y visuales hacen simultáneamente explícitos al espectador, transformándolas en objetos de análisis: a) la súbita transición interaccional de un régimen de acción "guionizada» (actuación) a otro de acción «natural» (espontaneidad), y b) la relación natural y banalmente reflexiva que vincula una situación social concreta con los dispositivos mecánicos de observación y registro (vgr., tecnologías de audio y videograbación) presentes en ella. Pues sus detalladas exigencias visuales y auditivas resisten los más variados y reiterados esfuerzos académicos de apropiación en exclusiva de este término como atributo distintivo del razonamiento científico — programas de «epistemología», «meta-teoría», «meta-metodología», "sistémico-cibernéticos», "hermenéutico-pragmáticos», «hermenéutico(auto)-críticos», «auto-referenciales», «auto-organizados», «reflexivo-radicales», etc. ${ }^{14}$ _, la «toma falsa» más «petarda» del programa más "cutre» de la televisión más «comercial» hace explícita, vulgar y despreciablemente evidente a la espectadora más «pasiva» de todas cuantas se hallan repantingadas en su sillón la «reflexividad de la acción social» en tanto que fenómeno social, esto es, como un atributo constitutivo de la actividad ordinaria - carente, por tanto, no sólo de «suplemento», sino también de remedio o alternativa «científica»15.

«Opino que los estudios etnometodológicos del discurso y la acción práctica pueden ayudarnos a disolver el cuadro referencial que sirve de marco a la oposición entre "epistemologías" objetivistas y reflexivas. La versión etnometodológica de la reflexividad constitutiva no propone una contraparte no-reflexiva. La reflexividad "esencial" de los informes situados que hacen las personas en su actividad diaria es ordinaria y, por tanto, específicamente "carente de interés" (y no una proyección trascendental de una presunta posición epistemológica de carácter "esencialista"); forma parte de la infraestructura de la comunicación objetiva del mismo modo que lo son los esfuerzos auto-conscientes para intentar ser reflexivo. Consecuentemente no existe ninguna razón especial para estar a favor o en contra de una concepción tal de la reflexividad. En algunos casos, los estudios sobre "nuestras propias" prácticas de investigación pueden ser interesantes, iluminadores o

14 Véase, por ejemplo, sin ir más lejos, A. J. Izquierdo, «Antropismo social, reflexividad estadística y liberalismo avanzado», en R. Ramos y F. García-Selgas (dirs.), Globalización, riesgo, reflexividad. Tres temas de la teoría social contemporánea, Madrid, CIS, 521-556.

15 De hecho, el trabajo de «remediación» científica de la práctica del espectador de televisión consistiría a su vez en una práctica de la misma naturaleza (irremediable) que la pretenden remediar (véase H. Garfinkel, Ethnomethodology's Program, Lanham (Maryland), Rowman and Littlefield, 2002, 101, n. 17). La etnometodología garfinkeliana, como ha escrito Philip Agré, es fundamentalmente «un proyecto ético que trata de proteger el lenguaje indígena frente a los intentos de usurpación y transcodificación llevados a cabo bajo los auspicios de sistemas intelectuales, sean éstos sociológicos o técnicos o de cualquier otro signo. Con lo cual rechaza que sus descubrimientos puedan ser reapropiados como recursos para subsiguientes usurpaciones del mismo tipo" (Agré, «Hazards of Design: Ethnomethodology and the Ritual Order of Computing», ponencia presentada en la Conferencia Anual de la Asociación Americana de Sociología, Sesión sobre Etnometodología: estudios híbridos sobre el trabajo, San Francisco, agosto 1998, 23). 
estar hábilmente escritos, o bien pueden resultar tediosos, pretenciosos o vacíos... De modo que ¿qué ganamos adoptando una versión de la reflexividad que no implica antónimo alguno, no nos confiere ninguna ventaja metodológica, y no coloca a ninguna teoría particular del conocimiento, a ningún lugar cultural o postura política por encima de ninguna otra? Si la reflexividad brilla igual para todos y para nadie en particular y su modo de iluminación no se halla controlado por ninguna teoría, método o posición subjetiva especial, entonces este concepto pierde su aura metafísica y se torna ordinario. Las esperanzas de ilustración y emancipación política deberán en este caso volver a las calles, que es el lugar adonde verdaderamente pertenecen ${ }^{16}$.

Otra mina de oro para la investigación videográfica de los modos de «organización y analizabilidad natural de las prácticas sociales» son los llamados "gazapos televisivos» (bluppers): errores flagrantes de dicción o lectura cometidos por presentadores de informati$\operatorname{vos}^{17}$, errores de ejecución de movimientos de precisión cometidos por deportistas profesionales y, en general, todo tipo de torpezas físicas impremeditadas y aparentes (desde las típicas caídas y tropezones a los múltiples atentados «fisiológicos» contra la cortesía interaccional, como flatulencias o eructos, «risa floja», «embriaguez» patente y todo tipo de acciones evidentemente «fuera de lugar») cometidas por cualesquiera personas y recogidas «en directo» por las cámara de cine o vídeo.

En realidad, como ha puesto de manifiesto un original estudio sobre los pormenores técnicos y sociales del trabajo de registro audio-videográfico de una actividad profesional particular (la de las comadronas que pasan consulta ginecológica a domicilio a mujeres que acaban de ser madres), la descripción de cómo se llevan a cabo justamente las tareas más ínfimas y despreciables de todas las que exige el cumplimiento exitoso de la labor de investigación social —como puede ser la elección del momento oportuno para encender la maquinaria de registro de datos (audiograbadora o cámara de vídeo)— puede aportar conocimientos muy valiosos sobre la organización de las prácticas sociales objeto de investigación.

16 M. Lynch, «Against reflexivity as an academic virtue and source of privileged knowledge», Theory, Culture, and Society, $2000,17,27-53,47-48$.

17 Véase E. Goffman, «Radio Talk. A Study of the Ways of Our Errors», en Goffman, Forms of Talk, Philadelphia (Penn), University of Pennsylvania Press, 1981, 197-330, para una completísima y sutilmente detallada exposición del catálogo teórico (facticidad, publicidad, descriptibilidad natural, analizabilidad natural, reflexividad natural, irreparabilidad, etc.) de las propiedades de orden características de la «sociedad ordinaria inmortal de Durkheim» (Garfinkel, Ethnomethodology's Program, op. cit., 143), tal como se exhiben, de forma estrictamente sonora, en y en tanto que los métodos de producción de los «gazapos» (vgr., los errores lingüísticos) cometidos por los locutores en la lectura de cuñas radiofónicas — «nuestro objeto de estudio no es el error en el habla [speech error] sino el error en la producción del habla [speech production error]» (Goffman, «Radio Talk», op. cit., 219). 
«Cuando se los analiza reflexivamente, los intentos llevados a cabo por una de las comadronas para influir en la decisión de la investigadora referente al mejor momento para encenderse la cámara de vídeo, nos proporcionan información muy valiosa sobre el modo específico cómo las comadronas organizan, diferenciándolas, las diversas partes de su labor profesional, y al hacerlo así, se orientan hacia y se ocupan de los tabúes sexuales [que hace visibles su trabajo de examen ginecológico]»18.

Presento en lo que sigue algunos resultados, aún muy preliminares, de un estudio sobre la existencia de un conjunto de procedimientos prácticos, analíticamente considerados en tanto que métodos cooperativos específicos para la restauración del sentido común de la realidad, y descritos razonadamente a partir de las «secuencias de revelación» (SRs) de una muestra de bromas de cámara oculta (en adelante, BCOs) grabadas de la televisión.

El estudio emplea como material de análisis grabaciones de vídeo de distintas emisiones sucesivas del programa de bromas de cámara oculta ;Ojo: que nos ven!, emitido por Telemadrid en las temporadas 2001 y $2002^{19}$. Los vídeos emitidos por el programa muestran escenas donde personas que llevan a cabo sus actividades ordinarias de forma espontánea (las «víctimas») son, de algún modo, embaucadas o, más bien, conducidas intencionalmente a error en sus apreciaciones de la escena que están viviendo con ellas por otras personas («actores» y «ganchos») que actúan de acuerdo con un plan de acción explícitamente preparado y explícitamente ocultado 20.

En su gloriosa e ineludible ordinariedad, lo «minúsculo particular» ${ }^{21}$ que habita en todos y cada uno de los detalles audiovisuales de estos pequeños fragmentos televisivos ofrece al

\footnotetext{
18 H. Lomax y N. Casey, «Recording Social Life: Reflexivity and Video Methodology», Sociological Research Online, 1998, 3 (2), 8.4 (http://www.socresonline.org.uk/socresonline/3/2/1.html).
}

19 Este formato, producido por Euskal Telebista en colaboración con otras televisiones autonómicas, es la secuela con «estrellas anónimas» de un programa anterior de BCOs con personajes famosos como víctimas titulado Inocente, Inocente, producido también por las televisiones autonómicas.

20 El material objeto de investigación está constituido por el fragmento final de una muestra general de 49 BCOs emitidas por una cadena de televisión de propiedad pública y registradas en un vídeo casero, aunque para el presente estudio he empleado solamente material extraído de una submuestra de 10 fragmentos. Mientras que, considerada en su totalidad como la longitud temporal de cada fragmento unitario construido como «una broma» por los productores del programa, la duración de una BCO completa oscila entre los cinco y los ocho minutos, la duración del fragmento final de la grabación de cada broma oscila entre los cinco y cincuenta segundos. Es este fragmento final el que hace visible-audible a sus espectadores-auditores la producción de un peculiar episodio de interacción social que he denominado secuencia de revelación (SR). El procedimiento recursivo de detección que he empleado para decidir cuándo exactamente da comienzo una SR —y, por tanto, dónde exactamente ha de comenzar la digitalización de la grabación analógica original y dónde exactamente comenzar la transcripción textual del fragmento de vídeo digitalizado- ha consistido, en realidad, en preguntarse cómo comienza el actor a deslizar la información secreta que ha estado ocultando a la víctima desde el inicio de la grabación.

21 «The sanctity of minute particulars» o «la santidad de lo minúsculo particular», según la expresión acuñada por el poeta inglés William Blake (citado en G. Steiner, Después de Babel. Aspectos del lenguaje y la traducción [1978], Madrid, Fondo de Cultura Económica, 1995, 16). 
investigador que se aplica a su observación con el interés y la atención suficientes un recorrido exhaustivo y detallado por el entero edificio conceptual de la filosofía y la metodología de las ciencias sociales. Disponemos además de sólidos argumentos, tanto teóricometodológicos como principalmente empíricos, avanzados por diferentes investigadores, para justificar y defender el estatuto propio de los datos videográficos como materiales de estudio singularmente adecuados — bien que radicalmente no aproblemáticos - para la específica tarea de investigar el cómo de las prácticas sociales de investigación científicosocial.

«Los documentos audio-visuales constituyen los recursos primarios de la investigación social»22.

«La capacidad del vídeo para registrar las actividades ocasionales de los participantes en tanto que sujetos de investigación implica que la cámara de vídeo es el instrumento de investigación [social] por excelencia, en la medida en que proporciona un medio exclusivo para explorar de modo reflexivo la naturaleza socialmente constitutiva del proceso de investigación»²3.

En todos los vídeos examinados, la situación incómoda o embarazosa —cuando no abiertamente pánica - hacia la que les orientan tanto la ambientación controlada (set) del entorno como la maquiavélica interpretación de actores y ganchos hace palpables a las víctimas de la broma una serie de métodos específicos de alteración (¿deconstrucción?) de la realidad — por cuanto atentan contra la lógica, el orden, la causalidad, la racionalidad, la fiabilidad, la previsibilidad, la autenticidad, etc., «establecidos»-. En concreto, el corpus escogido de fragmentos videográficos de BCOs cuya primera explotación presento aquí exhibe al espectador, en una riqueza y finura de detalle imposible de alcanzar por el análisis escritoconceptual, el siguiente fenómeno: la restauración del sentido ordinario de la realidad como logro interaccional.

22 Garfinkel, Ethnomethodology's Program, op. cit., 148.

${ }^{23}$ Lomax y Casey, «Recording Social Life», op. cit., 8.5. Para otras posturas metodológicas convergentes en el sentido de tratar simultáneamente a las tecnologías de audio-videograbación como objetos y como instrumentos de la investigación social, cf. C. Goodwin, «Professional Vision», American Anthropologist, 1994, 96 (3), 606-633, 607, y C. Heath y P. Luff, Technology in Action, Cambridge (UK), Cambridge University Press, 2000, 247. Para una investigación correlativa sobre la encuesta telefónica como recurso (tecnología) y como objeto (práctica social) de la investigación social, vid. D. W. Maynard y N. C. Schaeffer, «Toward a Sociology of Social Scientific Knowledge: Survey Research and Ethnomethodology's Asymmetric Alternates», Social Studies of Science, 2000, junio, 323-370. 


\section{LITERALIDAD Y SOBREINTERPRETACIÓN: DOS SECUENCIAS DE REVELACIÓN (SRs) ACCIDENTADAS}

Aunque es de todo punto imposible formular una regla general al respecto ${ }^{24}$, he aquí algunos fenómenos comunicativos evidentes que suelen funcionar como indicadores fiables del inicio de la secuencia de revelación: 1) la primera aparición registrada de palabras como «televisión» o "cámara» (a las que he dado en llamar palabras mágicas) en un contexto conversacional en que carece aparentemente de toda motivación retrospectiva al tiempo que, desde un punto de vista prospectivo, proporciona la clave para entender el desarrollo subsiguiente de la acción (vgr., la revelación de la broma) ${ }^{25}$; 2) la formulación inicial de expresiones retóricas coloquiales del tipo «¿Sabes una cosa?» («¿Sabes lo que te digo?», «Pues ¿sabes que te digo?», etc.); 3) o bien el asombro primigenio que asalta al espectador al ver cómo el actor lanza por primera vez una mirada «extraña» hacia el frente de la víctima, una mirada evidentemente «dirigida a nadie», esto es, dirigida hacia ese tercero invisible que es la cámara oculta (vgr., el espectador mismo que mira hacia la pantalla). Es éste uno de los gestos característicos con los que el actor suele iniciar un parlamento explicativo dirigido al público espectador —lo que en la jerga teatral se conoce como «hacer un aparte»- Por su parte, la elección del punto donde concluye la secuencia se atiene a un principio pragmático más sencillo: el corte al que sigue la (re)aparición de los presentadores del programa ${ }^{26}$.

La descripción razonada de la pragmática interaccional de los intercambios conversaciones mediante los que sus participantes ponen fin a una $\mathrm{BCO}^{27}$ me ha servido, en primer lugar, para elaborar un sencillo modelo heurístico tentativo de los componentes funda-

\footnotetext{
24 Caso de existir, lo cual es muy dudoso, el descubrimiento de una regla tal permitiría justamente hacer realidad uno de los sueños más húmedos del ingeniero de sistemas de inteligencia artificial: mecanizar el procedimiento de inferencia práctica en situación que conduce a formular distinciones pertinentes entre lo verdadero y lo falso, la apariencia y la realidad (cf. D. Sperber y D. Wilson, La relevancia. Comunicación y procesos cognitivos [1986], Madrid, Visor, 1994). Sobre la problemática práctica del diseño de sistemas de inteligencia artificial, vid. L. Suchman y R. Trigg, «La inteligencia artificial como artesanía», en S. Chaiklin y J. Lave (eds.), Estudiar las prácticas. Perspectivas sobre actividad y contexto [1996], Buenos Aires, Amorrortu, 2001, 159-231, y P. Agré, Computation and Human Experience, Cambridge (UK), Cambridge University Press, 1997.
}

25 Cf. A. V. Cicourel, Cognitive Sociology. Language and Meaning in Social Interaction (Londres, Penguin, 1973, 54-55), sobre el sentido retrospectivo-prospectivo que poseen las ocurrencias lingüísticas en las conversaciones ordinarias.

26 En el programa ;Ojo: que nos ven! cada clip está precedido, a modo de introducción, y va seguido, a modo de epílogo, por breves cuadros humorísticos interpretados por una pareja de presentadores sobre la base de un guión previamente escrito.

27 El trabajo de transcripción de la submuestra de fragmentos audio-videográficos seleccionados ha sido realizado con la asistencia del paquete informático Transana Versión 1.11 (copyright 1995-2002, The Board of Regents of the University of Wisconsin System). Para la extracción en formato de «mapa de bits» (.bmp) de los fotogramas insertos con los que he pretendido documentar algunos de los comportamientos no verbales más destacables de entre los descritos (verbalmente) en el texto de las transcripciones me he servido de una copia de evaluación del programa de captura de pantallas Snaglt Versión $6.12^{\odot}$ (copyright 1996-2002, Techsmith Corporation). 
mentales de esta fase final de la broma que he denominado secuencia de revelación (SR). Un primer procedimiento que puede resultar útil para mostrar el carácter distintivo de este modelo consiste en compararlo con un modelo analítico desarrollado para dar cuenta de algún fenómeno sociológico similar, como el modelo de los «cuatro movimientos» elaborado por Goffman para dar cuenta del elaborado procedimiento cooperativo de producción interaccional —que él denomina «salvar la cara»- que suelen emplear los sujetos que participan en una secuencia de «intercambio social» para lograr ese desideratum de la sociabilidad cara a cara que la razón común llama «actuar con tacto», o bien «nadar y guardar la ropa» ${ }^{28}$. Otra comparación, algo más ajustada, si no más elaborada, que puede servirnos para comenzar a desbrozar la morfología del modelo analítico de la $\mathrm{BCO}$, esa institución social característica de la «sociedad mediática», es la analogía con el viaje en avión. Tras haber hecho a la víctima «despegar los pies del suelo» con algún engaño bien diseñado y haberla luego mantenido en el aire, alejada de la realidad, sometiéndola y sometiéndose a turbulencias y altibajos de diversa magnitud y aun a algún que otro conato de caída libre, actores y ganchos tratan, al cabo de un corto período de vuelo en el que se han divertido (o bien han sufrido) de lo lindo, de iniciar maniobras de descenso, aproximación y toma de pista. Siguiendo esta metáfora del vuelo, pueden distinguirse tres fases en el desarrollo de una broma: despegue, trayecto y aterrizaje. Mi trabajo examina exclusivamente la tercera fase, el aterrizaje de la broma, que denomino secuencia de revelación (SR) ${ }^{29}$.

Para fines expositivos podemos segmentar analíticamente la maniobra final de aterrizaje de una broma, la SR, en dos fases o sub-secuencias ${ }^{30}$ :

a) Una primera fase, que suele ser la más larga de las dos, en la que el actor o actores que llevan a cabo la broma realizan un trabajo verbal y corporal bien explícito y visible para

28 E. Goffman, «Sobre el trabajo de la cara: análisis de los elementos rituales en la interacción social», en Goffman, Rituales de Interacción [1967], Buenos Aires, Tiempo Contemporáneo, 1970, 13-47, cit., pp. 25-26, 27.

29 Obsérvese, por cierto, que el carácter exitoso o accidentado del aterrizaje final de la broma es relativamente independiente del modo, cómodo o incómodo, como se desarrollaron las dos fases anteriores del vuelo. En este sentido, una broma despiadada y humillante puede cerrarse perfectamente de la forma más gentil y amigable (e.g., «iqué cabrón!», «jeres una puta!», dichas con una sonrisa y en tono amistoso), del mismo modo que un vuelo agradable puede, como consecuencia de un fallo ocurrido en el último momento (e.g., en presencia de víctimas «altamente herméticas» el actor no posee indicios suficientes para saber cuándo y cómo puede hacer caer «la gota que colma el vaso», de modo que, si persiste en tensar la cuerda, corre el riesgo de que «se le vaya un poco la mano» en los últimos gags), terminar «estrellándose contra el suelo» (e.g., la víctima rompe a llorar o bien les rompe la crisma a actores y ganchos). Aunque también, por supuesto, sucede con frecuencia que la violencia creciente de una sucesión de turbulencias acaecidas durante el trayecto puede ocasionar un pánico colectivo en el pasaje o bien dañar gravemente la estructura del aparato, obligando a la tripulación a improvisar (un plan de) aterrizaje de emergencia u ocasionando, en el peor de los casos, una caída en picado irremisible del aparato.

30 Aunque en la práctica el inicio de la segunda se solapa muchas veces con el final de la primera, difuminando así los límites arbitrarios impuestos por el decreto teórico. 
la eventual espectadora cuyo propósito es «revelar» a la víctima de la broma el carácter «artificial», «construido» o «irreal» de la situación en la que se halla inmersa.

b) Una segunda parte, casi siempre más corta que la primera (aunque las excepciones, numerosas, a esta regla ofrecen un interés especial para este análisis), en la que la víctima, por medio de respuestas verbales y gestuales, muestra a su interlocutor (y a los espectadores) su disposición/negativa a aceptar el cambio en la «definición de la situación» que le ha sido ofrecido.

Vayan ahora una serie de observaciones complementarias, ligeramente más específicas, sobre los contenidos de ambas fases:

i) El (teórico) orden conversacional «característico» de la primera parte de la SR de una BCO permite en general turnos de palabras largos e ininterrumpidos: las «explicaciones» de los actores de la broma, frecuentemente precedidas de una pregunta introductoria («¿Sabes lo que te digo?», «¿Tú dónde ves la televisión?», «¿Te han hecho alguna vez un vídeo familiar?», «¿Sabes por qué te lo digo?»).

ii) En la segunda parte de la SR, los signos, perfectamente visibles y audibles las más de las veces - y en general inequívocos-, de aceptación (e.g., movimientos de asentimiento con la cabeza, sonrisas, carcajadas) o rechazo (e.g., movimientos de negación con la cabeza, desplantes, empujones, golpes, llanto) que producen de modo casi inmediato las víctimas de una BCO una vez han sabido del cambio en la definición de la situación que les ofrecen actores y ganchos, suelen desplegarse conversacionalmente en la forma de un patrón característico de alternancia de turnos cortos de palabra que se solapan e interrumpen entre sí.

iii) En tierra de nadie de la interfase, y por tanto como cabeza de puente entre las dos fases de la SR, surge a veces un período de confusión, que puede prolongarse, con efectos altamente hilarantes, hasta límites disparatados. De hecho, cuando es hecho aparecer por los protagonistas de la escena - y siempre lo es de forma impremeditada-, este intervalo intermedio del espectro energético de la broma suele acabar «atrayendo» hacia su interior la mayor parte de potencial humorístico de la misma. Para poder abrir este interludio imprevisto dentro de la situación, la víctima intenta, a veces de forma inocente, otras de modo patético, negar («¿Sí? A mí no»), ignorar, dudar de («¿Qué haces?») y, en general, minimizar o quitarle yerro («No me importaría») a la notificación de traslado de domicilio situacional que le acaba de enviar el actor («¿Seguro que no te importa que no haya televisión?», «Pues ahí hay una cámara, ahí hay otra...», «Le denuncio públicamente»). A tal fin es capaz de elaborar todo tipo de interpretaciones defensivas, explicaciones críticas realmente 
elaboradas que van desde la réplica literal y pertinente (SR-19) a la sobreinterpretación aguda (SR-23), pasando por el diagnóstico clínico (SR-40; no incluida aquí) ${ }^{31}$.

\section{Secuencia 1 [SR-19] - Período de confusión (réplica literal)}

((Plano 2: plano medio, V, mujer joven, sentada en una mesa. G, otra mujer joven, se sienta a su derecha en la imagen, y más allá, de frente a $\mathbf{V}$, aunque sentado mirando hacia el espectador, está $\mathbf{A}$, un hombre joven))

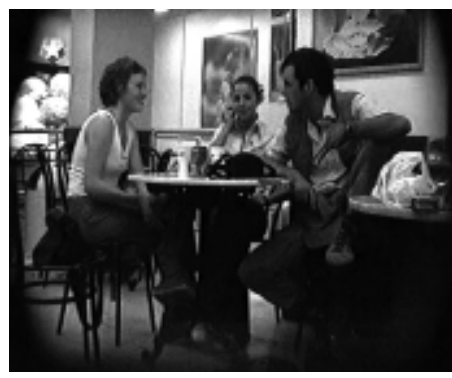

1 A: ¿Seguro que no te importa que no haya televisión? ((Cambia a Plano 1: vemos solamente a V en primer plano))

2 V: Sííi ((ríe))

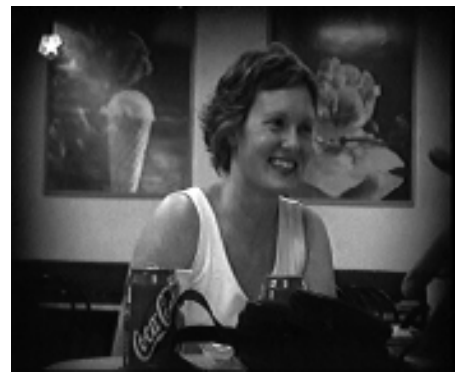

3 A: ¿eh?

31 Vayan aquí una serie de instrucciones preliminares para la lectura de las convenciones tipográficas empleadas en la transcripción de las secuencias audio-videográficas (notación jeffersoniana abreviada acompañada de fotogramas insertos): 1) los números entre paréntesis señalan la duración de una pausa en décimas de segundo (un punto entre paréntesis indica una pausa menor de dos décimas de segundo); 2) un guión al final de una palabra indica una interrupción de frase; 3) las frases entre paréntesis son transcripciones candidatas de escuchas problemáticas o ambiguas; 4) los dobles paréntesis contienen descripciones de acciones y gestos visuales; 5 ) los corchetes se emplean para dar cuenta del punto donde se solapan dos o más turnos de palabra, y 6) las flechas que anteceden a algunos números de línea se emplean para llamar la atención del lector sobre la importancia del contenido del turno en cuestión para fines del presente análisis. 
4 V: Seguro que no me [importa] ((riendo))

5 A:

\section{[}

[¿Seguro?]

6 A: Pues a mí me parece un gran problema, ¿eh?

((Hace un gesto extendiendo la palma de su mano izquierda)) ((Cambia a Plano 1))

7 V: ((Sonriendo)) ¿Sí? A mí no

8 A: ¿eh?

9 V: A mí no

10 A: ¿Entiendes por qué o no? (0.8)

11 V: ¿Que por qué me parece unnnn- un gran prob((con expresión seria))

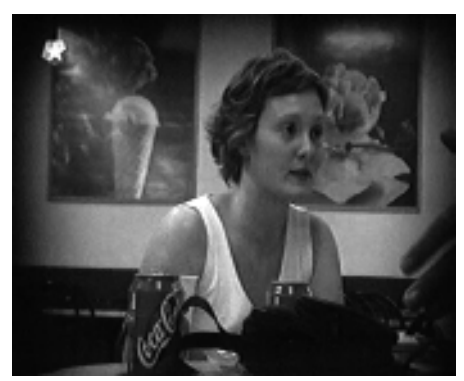

12 V: por qué te parece un gran [problema]?

13 A: [Sí]

((Cambia a Plano 2))

14 A: Que no haya [televisión]

$15 \mathrm{~V}$ : [Para ver las noticias]

o algo de eso (( $\mathbf{A}$ y $\mathbf{V}$ se miran fijamente $))$

16 A: No:: hombre

((hace un gesto de negación levantando su brazo derecho)) 


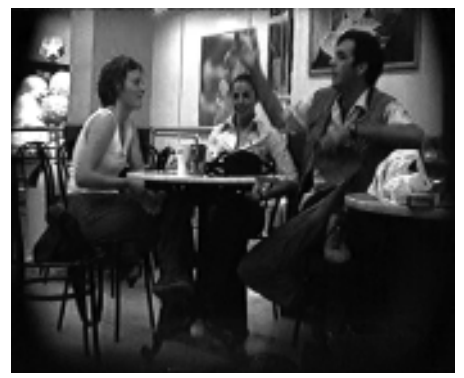

17 A: para ver las noticias no, para ver algo ((Cambia a Plano 1))

$\rightarrow 18$ A: mucho más importante,

19 V: ((Mira a A con expresión concentrada))

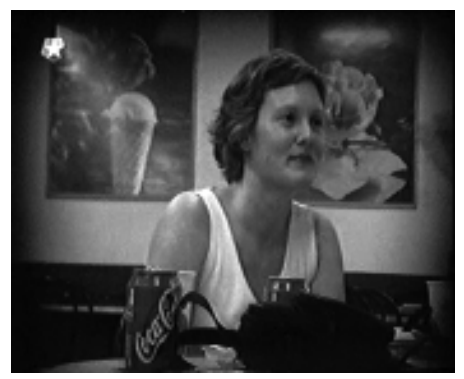

20 A: para verte a ti en la televisión

El actor comienza en este fragmento proporcionando la primera «pista» para resolver el enigma (la palabra mágica «televisión»), bajo una fórmula interrogativa característica destinada a señalar a la víctima — de hecho, a tratar de convencerle- del carácter más bien precario de sus (¡del actor!) anclajes emocionales para con la situación (I. 1: «¿seguro que no te importa...?»). Sigue un largo, absurdo toma y daca conversacional (Is. 2-11), verdadero «diálogo de besugos» hecho de preguntas (I. 10: «¿Entiendes por qué o no?») y de preguntas sobre el significado de las preguntas precedentes (Is. 11-14: ¿Que por qué me parece / te parece un gran problema / que no haya televisión?). En estas líneas (10-14), mientras que el actor trata de hacer evidente a la víctima la posibilidad de que sus muestras de seguridad se apoyen en un malentendido sobre el contexto conversacional relevante dentro del cual está siendo interpretado el vocablo «televisión», la víctima replica afianzando sus garantías de competencia y buen entendimiento conversacional y tratando de sostener su propia definición previa de la situación. El clímax final, de efecto altamente hi- 
larante, se produce con la sucesión de afirmaciones contrapuestas: al inocente aserto literal de la víctima «Para ver las noticias» (I. 15) replica deleitosamente el actor prolongando y troceando su largamente esperado golpe final en forma de tres «hachazos» separados (Is. 16-20): 1) un desmentido categórico («Nooo hombre, para ver las noticias no»); 2) un redoble de tambor («mucho más») que anuncia la «importancia» de lo que se avecina («para ver algo mucho más importante»), y, finalmente, 3) la pirueta mortal («para verte a ti en la televisión»), cuya fatal potencia de desencantamiento se concentra en su mayor parte en el efecto que produce colocar el deíctico personal («a ti») en el lugar previamente seleccionado por la víctima (como solución alternativa a un enigma conversacional emergente) y ofrecerlo astutamente como sustituto exacto, a la vez que radicalmente opuesto, del tópico mediático convencional («las noticias») inocentemente traído a colación por ésta en primera instancia.

Secuencia 2 [SR-23] - Período de confusión (sobreinterpretación)

((Plano 1: plano medio, en el centro de la imagen vemos a $\mathbf{V}$, varón joven, sentado en medio de: A2, mujer joven, sentada a su derecha - la izquierda del espectador- en el mismo sofá, y A1, mujer joven, sentada a su izquierda — derecha del espectador- en otro sofá))

1 A1: Nunca te han hecho un vídeo familiar, vamos

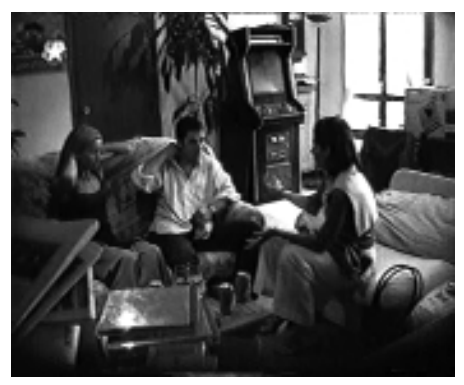

((Cambia a Plano 2: Primer plano de V, en el centro de la imagen)) 


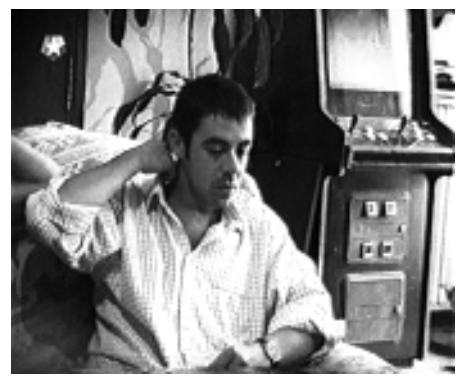

(0.5)

2 V: Sí

((Corte edición. Cambia a Plano 1))

3 A1 y A2: ((Al unísono)) Pues ahí hay una cámara

((señalando con sus manos enfrente de $\mathbf{V}$ hacia arriba))

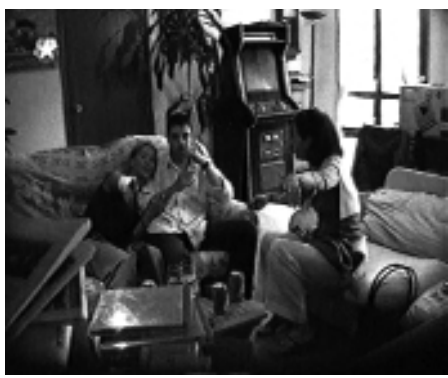

4 A2: Ahí hay

((señalando con su mano enfrente de $\mathbf{V}$ hacia abajo))

((Cambia a Plano 2))

5 A2: [otra]

6 A1: [no se entiende]

7 A1: ((Señala con su mano derecha hacia el frente y hacia arriba mientras que con su mano izquierda le toca a $\mathbf{V}$ su brazo derecho; a su vez $\mathbf{V}$ está iniciando un gesto acercando sus manos al pecho)) 


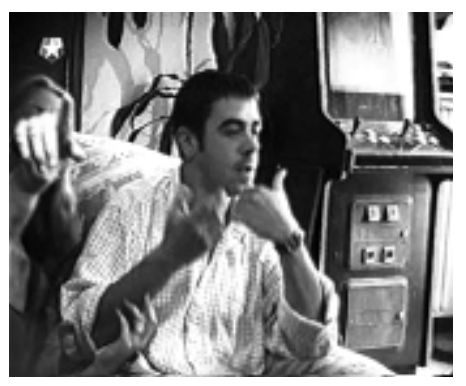

8 A1: $Y$ por ahí tienes

$\rightarrow 9$ V: [Sí tendría]

10 A1: [otra]

11 V: ((Mueve la cabeza, lleva su mano izquierda hacia su barbilla y se queda mirando fijamente enfrente suyo))

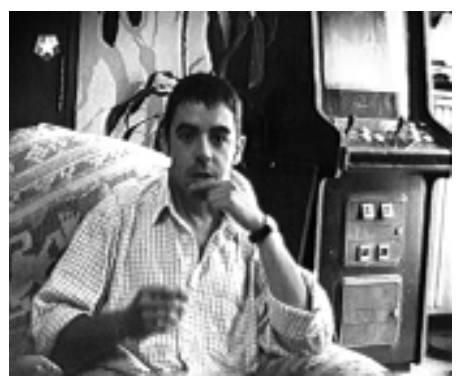

$\rightarrow 12$ V: Sí tendría inconveniente en grabar, en grabarme a mí mismo

13 A2: ((Carcajada))

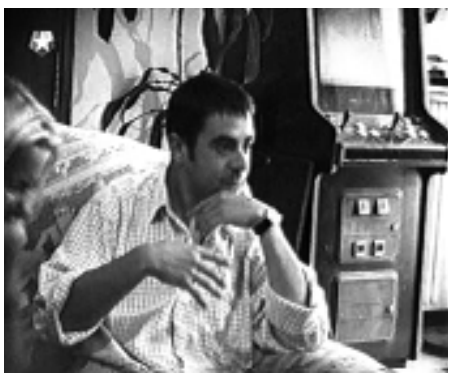

14 V: ((Lanza una risa nerviosa hacia A2))

$\rightarrow 15$ A2: Es que esto es una broma, ji, ji 
((Mientras dice esto $\mathbf{A} 2$ coge la mano derecha de $\mathbf{V}$ con la suya))

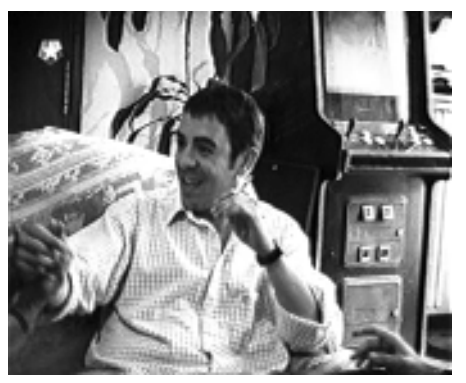

Este segundo caso, por la complejidad del tipo de confusión surgida, posee, desde mi punto de vista, especial interés analítico. Al comienzo del fragmento, una de las actrices inquiere «Nunca te han hecho un vídeo familiar, vamos» (I. 1). A lo que la víctima responde que no (I. 2). A este intercambio sucede la revelación por parte de las actrices de la presencia de cámaras de vídeo dentro de la habitación (Is. 3-5). La relevancia del tema de la "grabación de un vídeo» como tópico conversacional queda ahora bien establecida. El problema es que el sentido de esta relevancia se bifurca (Is. 7-10): mientas las actrices refieren la presencia de cámaras de modo directo («ahí hay») y en tono divertido, la víctima emplea un modo condicional («sí tendría») que, retomado en la I. 12, sirve como prefacio para una negativa elaborada («inconveniente») aplicada a una predicación altamente redundante («grabarme a mí mismo»). En efecto, la I. 12 desarrolla plenamente el potencial problemático de la tentativa de respuesta de la víctima frente a las revelaciones que acaban de hacerle las dos actrices. Lo problemático de una «afirmación negativa» («Sí tendría inconveniente en grabarme a mí mismo») tan cuidadosamente formulada en lo que tiene de reiteración reflexiva («grabar-me-a-mí-mismo») es que puede ser oída por las actrices, y éste parece ser aquí el caso (vgr., el espectador puede literalmente «oír» él mismo que las actrices así lo oyen), como una observación palpablemente predicada sobre algo muy otro que una broma de cámara oculta, donde uno, por definición, no puede grabarse a uno mismo, sino que debe necesariamente «ser grabado» por otros.

El espectador sabe que esto es así no por ciencia infusa, sino porque se lo muestra la reiteración enfática (cogiéndole de la mano) del ofrecimiento de restauración que hace una de las actrices en el siguiente turno (I. 15: «Es que esto es una broma») $)^{32}$. Aquello que las

32 «En una conversación, la aparición de cualquier turno siempre se puede explicar a partir de la naturaleza de los turnos precedentes y/o siguientes» (A. Tusón Valls, El análisis de la conversación, Barcelona, Ariel, 1997, 58). Por otro lado, aunque el conocimiento de la identidad precisa del «objeto divergente» hacia el que se orientan las pesquisas inductivas de la víctima a partir de la línea 8 , no es relevante para fines del presente análisis una inspección somera de los intercambios conversacio- 
actrices señalan que está ocurriendo y aquello que la víctima señala que no desearía que (le) ocurriese son dos situaciones ficticias muy distintas, por más que tengan lugar dentro de la misma situación real — que es todavía de incertidumbre sobre cuál será, a corto plazo, su naturaleza propia-. (Empleo la expresión «sobreinterpretación aguda» a modo de taquigrafía para describir esa abrupta bifurcación en el sentido atribuido al tópico conversacional relevante para las dos partes en litigio.)

\section{DE LA BROMA PESADA: EL «ATERRIZAJE FORZOSO»Y LA «COLISIÓN»}

Desde los trabajos pioneros de Harvey Sacks sobre el análisis de la conversación, se conoce como «sistema de organización de preferencias» al mecanismo secuencial mediante el cual un turno de intervención inicial puede ser diseñado por su emisor de modo tal que implique para el oyente la existencia de un determinado tipo «preferencial» de turno subsiguiente. Este modelo permite dar cuenta de un hecho empírico masivamente prevalente: en el caso del par conversacional adyacente (adjacency pair) constituido por la unión secuencial de una «invitación» y de una de las dos opciones de respuesta que ofrece (aceptación o rechazo), el diseño de recepción (recipient desing) del primer turno o segmento del par (la invitación) prevé la «aceptación» como «respuesta favorecida» (preferred answer) y el «rechazo» como «respuesta desfavorecida» (dispreferred answer). Este tipo de diseño de recepción suele implicar, además, que aquellas respuestas que cumplen con la expectativa inferida suelen ser más cortas que aquellas otras que de algún modo la violan a sabiendas y que, por tanto, han de añadir algún tipo de explicación ${ }^{33}$. De este modo los turnos de rechazo se formulan como unidades proposicionales más elaboradas que los turnos de aceptación: suelen, por ejemplo, incluir pausas de retraso, prefacios («bueno...», «estooo...»), garantías («intentaré...») o fórmulas de excepción («a menos que»).

El ofrecimiento de los actores puede suscitar en las víctimas orientaciones positivas (a la aceptación) o bien negativas (al rechazo). Las orientaciones de las víctimas son explícitamente visibles en sus respuestas a las intimaciones del actor («Pues vas a salir en una broma de cámara oculta», «Te están viendo ahí», «¿Nunca te han hecho un vídeo familiar?», «Es un programa de televisión de cámara oculta», «Esto es una broma», etc.). Las respuestas de las víctimas a los intentos de restauración de los actores (a veces con la colaboración de los ganchos) se concretan en una infinidad de variantes lingüísticas (« ¿Es

nales inmediatamente precedentes al fragmento de transcripción analizado; basta para especular de modo informado sobre cuál pueda ser ese «objeto de grabación no identificado» —un vídeo de contenido sexual.

33 “[L]as respuestas preferidas tienen la forma que Sacks describe como "Sí y punto". Y las respuestas no preferidas son de la forma "No y algo más" (D. Silverman, Harvey Sacks. Social Science and Conversation Analysis, Londres, Polity Press, 1998, 123). 
una broma idiota?», «Yo no veo nada», “¿Lo dices en serio?», «No me lo creo», «¿Pero qué me está contando de una televisión?») acompañadas de los detalles audiovisuales, aun los más ínfimos, de un amplio repertorio de gestos y movimientos (miradas perdidas, ojos desorbitados, ceños fruncidos, ocultación del rostro con las manos, movimientos de manos, giros bruscos, convulsiones repentinas, carreras de ataque o de huida, intentos de agresión, gestos de resistencia a y/o rechazo de abrazos consoladores, etc.).

Cuando suceden, los rechazos formulados por las víctimas a los ofrecimientos de cambio de definición de la situación hechos por actores y/o ganchos se concretan en secuencias interactivas típicamente más elaboradas y complejamente prolongadas que las que implican aceptación. En estos casos, las «explosiones» de risa o llanto, visiblemente liberadoras de la tensión y la incertidumbre acumuladas, se cuentan entre las respuestas más típicas de la víctima a los ofrecimientos de restauración de actores y ganchos. Así, por ejemplo, en el tipo de secuencia que denomino "aterrizaje forzoso», las palabras mágicas que el actor tenía previsto pronunciar para iniciar el descenso son pronunciadas un poco demasiado tarde y con un tono apresurado y más bien desesperado: se dice «¡Que no, cariño!», «¡Es broma!» o «iQue es una broma para televisión!», cuando la víctima ya no tiene consuelo (SR-46) o bien ha cerrado unilateral e irreversiblemente el canal de escucha (SR-49).

\section{Secuencia 3 [SR-46] - Aterrizaje forzoso}

((Plano 1: plano medio de dos mujeres jóvenes sentadas en un sofá; $A$ a la izquierda de la imagen y $\mathrm{V}$ a la derecha; oímos la voz de $\mathrm{G}$ que está a la izquierda de la imagen pero fuera de cuadro))

15 V: [y yo] ((se le quiebra la voz))

]

16 A: [Mira una amiga]

((mientras sigue sujetando la mano de $\mathbf{V}$ con su mano izquierda, le da una palmada en la rodilla con la derecha))

17 V: ((con voz llorosa))

[no puedo pensar que tú me vayas]

18 A:

[y la mejor]

19 A: amiga de

((con sus dos manos le da a $\mathbf{V}$ un apretón en su mano derecha)) 


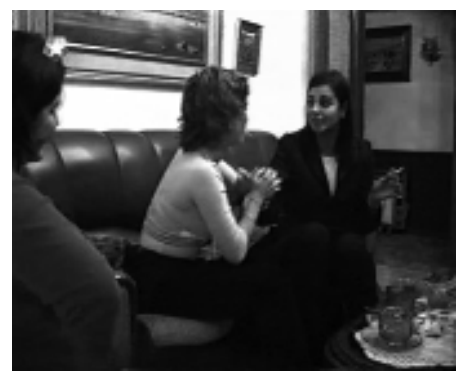

20 A: tooo

((levanta la mano de $\mathbf{V}$ con sus dos manos))

21 A: dos

((riendo, baja la mano de $\mathbf{V}$ hasta golpearle en la rodilla))

22 A: ((Levanta su brazo derecho e indica hacia el frente de $\mathbf{V})$ )

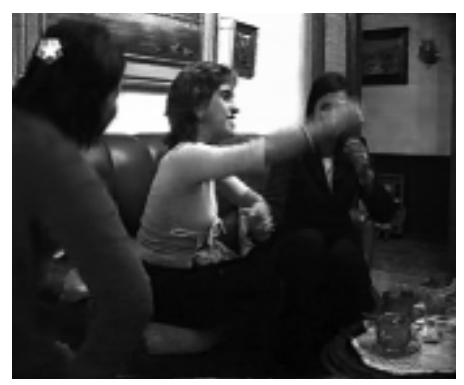

$\rightarrow 23$ G: ((Levantándose y yéndose hacia $\mathbf{V})$ )

24 G: ¡Que no, cariño!

25 V: ((Se lleva la mano derecha, en la que sujeta un cigarrillo, a la cara y «rompe a (lorar»))

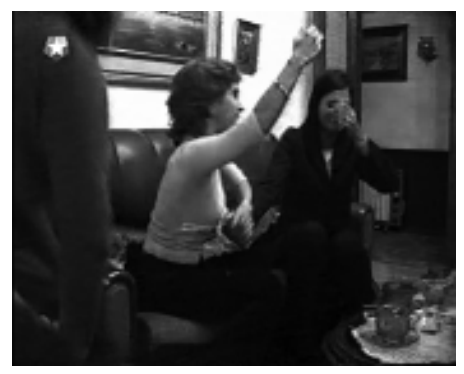

$\rightarrow 26$ A: Que saluda a la caaámara 


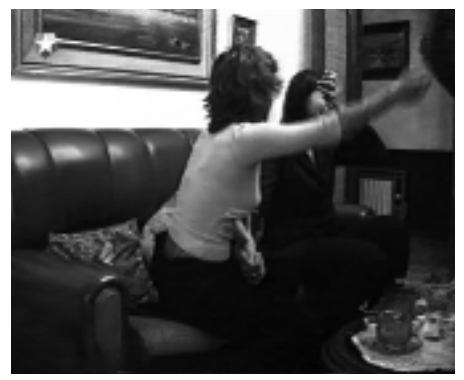

En este fragmento, el primer síntoma visible ofrecido por la víctima (se le quiebra la voz al decir «y yo», I. 15) del derrumbe que se avecina, aunque no ha podido ser anticipando ni por la actriz ni por el gancho, es rápidamente contrarrestado por ambas. En primer lugar, la actriz se apresura de forma inmediata (Is. 16-22) a tratar de contener el cada vez más inminente ataque de llanto de la víctima (I. 17), empleando tanto palabras («Mira una amiga [...] y la mejor amiga de todos») como, sobre todo, gestos: le coge de la mano y le da una palmada en la rodilla (I. 16); a continuación y casi simultáneamente (I. 19) le da un apretón de manos; sin solución de continuidad le alza luego la mano (l. 20) y la deja caer golpeándole en la rodilla (I. 21); y, finalmente (I. 22), le indica con su brazo la probable posición de una de las cámaras. A partir de entonces es la gancho quien toma la iniciativa, y de hecho el relevo de la actriz, para consumar el improvisado plan de aterrizaje forzoso de la broma: se levanta rápidamente de su asiento para ir hacia donde está la víctima (I. 23), al tiempo que grita «iQue no, cariño!» (I. 24). Más que conseguir evitar lo inevitable, los intentos de reparación sobre la marcha de actriz y gancho lo que realmente logran con su coreografía de interjecciones y movimientos es acelerar el momento pero, a la vez, contener dentro de límites aceptables la magnitud de la explosión de llanto de la víctima que eventualmente se produce en I. 25. Algunas de las palabras mágicas que, suponemos, tenía inicialmente previsto «sacarse de la chistera», esto es, decir «por sorpresa», la actriz, son pronunciadas ahora (I. 26) de forma terminal y más bien retórica (“Que saluda a la cámara»), mientras le señala con el brazo a la víctima en dirección al lugar donde presumiblemente están posicionadas las cámaras.

La especificidad y la finura de los métodos conversacionales e interaccionales que emplean los actores y ganchos para lograr llevar a cabo de modo exitoso un aterrizaje forzoso sólo se hace verdaderamente manifiesta cuando se compara una secuencia como la anterior con los resultados desastrosos de una broma, notoriamente pesada, que concluye del modo que he dado en denominar colisión. 
Secuencia 4 [SR-49] - Colisión

((Plano 2: Plano corto, fijo, del interior del bar, en medio de la imagen a dos hombres maduros, G2 y G3, que están mirando hacia la puerta del bar; escuchamos la voz de A, fuera de cuadro a la izquierda de la imagen))

3 A: ((A la izquierda de la imagen, entra corriendo en el bar con un objeto entre las manos y se dirige hacia la esquina trasera del local))

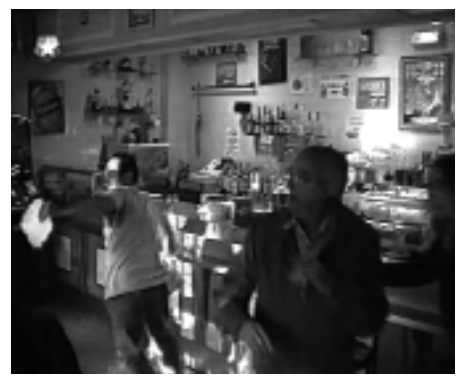

4 V: (Grita algo que no se entiende)

((Entrando en cuadro, en la parte inferior izquierda de la imagen, corriendo hacia $\mathbf{A})$ )

5 V: ((Es interceptado por G2, junto al que está G3 y también G4, una mujer joven))

6 A: ¡Vale, Paco, vale, que es una broma!

((En el margen izquierdo de la imagen, alzando los brazos y saliendo fuera de cuadro))

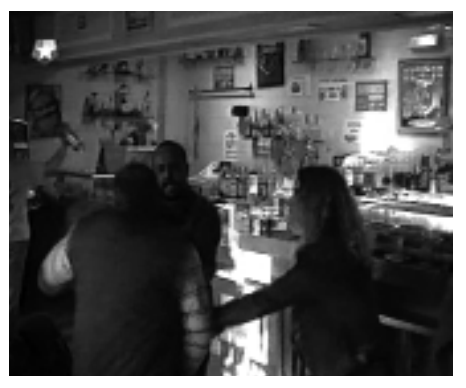

((Cambia a Plano 1: plano corto, tomado por una cámara en movimiento, que muestra a $\mathbf{V}$, asomando ligeramente la cabeza por entre el gentío en la parte superior derecha de la pantalla, tratando de zafarse de los sucesivos placajes que le van haciendo los clientes del bar e irse hacia $\mathbf{A})$ )

7 A: ((Ya fuera de imagen)) iquieto!

8 G3: ¡Paco! 
((El objetivo de la cámara se mueve hacia la derecha, siguiendo a $\mathbf{V}$, que lleva en su mano derecha una barra o bastón, y que, en medio de un griterío ensordecedor, va siendo desplazado hasta la puerta de salida del bar por dos mujeres, G1 y G5))

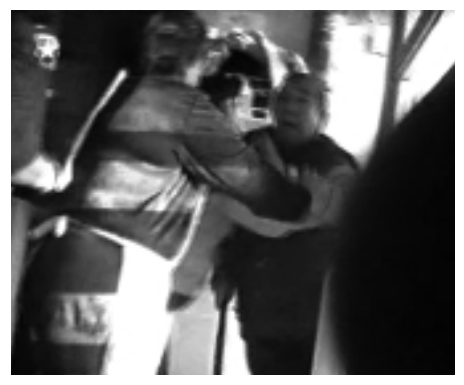

((Sigue el griterío))

9 V: ((Logra zafarse de G1 y vuelve a entrar en el bar: la cámara sigue su movimiento de desplazamiento que va de derecha a izquierda en la imagen))

10 A: ¡Paco! ((Fuera de imagen)) ((Griterío))

11 G1: ((Vuelve a interceptar a V y le empuja hacia la puerta de uno de los baños del bar, a la derecha de la imagen))

$\rightarrow 12$ A: ¡Que es una broma de televisión, Paco! ((Fuera de imagen))

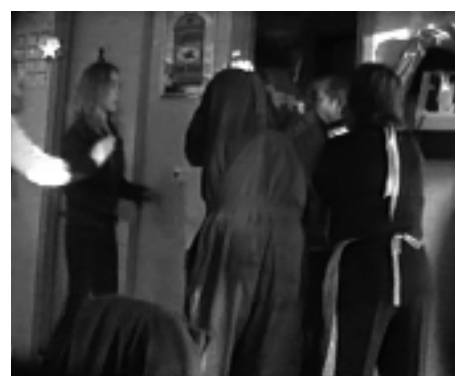

((Griterío: entre varios consiguen cercar a $\mathbf{V}$ en el umbral de la puerta del baño))

13 A: ¡Que es una broma! ((Fuera de imagen)) ((V sigue forcejeando en el umbral de la puerta del baño entre el griterío general)) ((Comienza sintonía de fondo, a volumen bajo))

14 A: ¡Paco! ((Fuera de imagen)) 


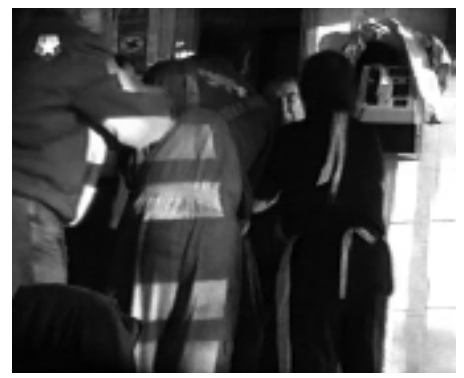

15 V: ((Rodeado por cinco personas, en el umbral de la puerta del baño, negando con la cabeza y con expresión muy enfadada, empuja a G5 a la derecha de la imagen))

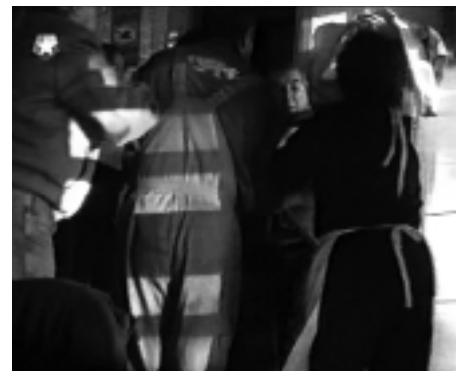

16 V: ((Tapado por el corro de gente, sigue forcejeando y tratando de irse a por A, que sigue fuera de la imagen; el griterío continua))

El empleo por parte de actores y ganchos de dos de las palabras mágicas esenciales para determinar analíticamente los contornos sociales del sistema interaccional de las BCOs, como son «broma» y «televisión», que en otros contextos suele ser definitivo, y aun inmediatamente efectivo para hacer aterrizar a la víctima, se hace aquí de un modo muy peculiar. Al gritarlas como parte de una exclamación ritual (I. 6: «iVale, Paco, vale, que es una broma!»; I. 12: «¡Que es una broma de televisión, Paco!», y I. 13: «¡Que es una broma!»), y salpicarlas además de modo intermitente con apelaciones nominales inespecíficas (los tres «iPaco!» que gritan sucesivamente el actor y los ganchos en Is. 8, 10 y 14), su poder de revelación queda ampliamente diluido a la vez por el tono pánico y el sentido genérico con el que son dichas. Además, por más que el actor, los ganchos e incluso, como sucede en este caso, una cantidad indeterminada, aunque no pequeña (suficiente, en cualquier caso, para producir la cosa organizacional que reconocemos como "griterío» o «algarabía»), de otras personas presentes en la situación, que en un principio parecían ajenas al plan de la broma, se esfuercen de modo desesperado e incluso dramático para intentar bajar a tierra a la 
víctima ${ }^{34}$, lo distintivo de un episodio prototípico de colisión como el que exhibe esta secuencia es justamente que esta última acaba teniendo éxito en su empeño. Una tarea que consiste en resistir-se, con todos los medios al alcance de uno - como, por ejemplo, la especie de bastón o barra que esgrime amenazadoramente la víctima de la broma (I. 8) - , a que la improvisada operación de salvamento de emergencia sea llevada a buen término. Y, de hecho, lograr «estrellar» la nave: es decir, «estrellarse», literalmente, contra sus tripulantes.

En conclusión, puede sostenerse que el término broma pesada (y sus derivaciones: e.g., «broma de mal gusto», «broma macabra», «broma imperdonable», etc.), en tanto que categoría específica de la sociología indígena que empleamos en la vida cotidiana ${ }^{35}$, solemos emplearlo para glosar de forma genérica justamente aquellos casos en los que la víctima exhibe de forma palpable, durante la segunda fase de la SR, una negativa, siquiera transitoria, a aceptar el cambio en la definición de la situación propuesto por el actor y los ganchos en la primera parte de la SR.

\section{CONCLUSIÓN: BROMAS Y ÉTICA CIENTÍFICA}

Entender la importancia de «en serio». Considerar las comparaciones siguientes: a) en serio como en una representación de verdad (eg., una proyección de vídeo como UCLA at Work es tomada en serio por la Oficina de Relaciones Públicas de UCLA [Universidad de California en Los Ángeles]); b) en serio como se juega un juego de preguntas y respuestas de verdad; $c$ ) en serio pensado como un escenario goffmanesco, «se tomaron la reunión en serio», etc. ${ }^{36}$.

El material de grabaciones videográficas con cámara oculta empleado en este estudio constituye una forma natural de ERs etnometodológicos. El carácter natural, espontáneo,

\footnotetext{
34 Algo que en este caso ya solamente podría conseguirse de modo forzado y brusco: esto es, si acaso la aparentemente caótica pero en la práctica organizadísima coreografía de desplazamientos, empujones, gestos y gritos producida «al efecto» llegara efectivamente a surtir algún «efecto».
}

35 Véase el siguiente fragmento extraído de una noticia aparecida en el suplemento local de un periódico de difusión nacional: «Fue la de ayer una amarga jornada para Antonio Carmona. A primeras horas de la mañana anunció su decisión de abandonar su escaño de diputado, tras una conversación con la dirección de la Federación Socialista Madrileña (FSM). Sus comentarios sobre el Prestige [un barco petrolero cuyo reciente hundimiento frente a las costas de Galicia había provocado una «marea negra» de efectos devastadores para el ecosistema costero], pronunciados en tono distendido, tras finalizar una reunión con comerciantes de Aranjuez, se hicieron públicos. El diputado socialista, ante las acusaciones de uno de los asistentes al acto de Aranjuez que le había recriminado que los políticos sólo se ocupan de los pequeños comerciantes para recabar su voto, replicó que el partido "iba sobrado de votos" y que si no hundían "otro barco". Y añadió a continuación "Es broma, es broma". Carmona comenzó así su particular calvario pidiendo disculpas y acusándose a sí mismo de haber hecho una broma imperdonable. Ayer entró en el registro de la Asamblea su renuncia» (R. Serrano, "La oposición alaba el "valor y la ética" de Antonio Carmona al presentar su dimisión», diario El País, suplemento «Madrid», viernes 13 de diciembre de 2002, 5; énfasis mio).

36 Garfinkel, Ethnomethodology's Program, op. cit. n. 15, 226. 
no fabricado o «encontrado» de estos experimentos permite al analista una defensa, creo que relativamente sólida, contra las denuncias de «inhumanidad», "sadismo» y "violación de las normas éticas de la investigación científica» dirigidas por diversos autores contra los experimentos etnometodológicos originalmente discutidos por Garfinkel ${ }^{37}$.

El problema de la ética investigadora de los ERs ha sido maravillosamente ilustrado por el sociólogo de la ciencia Michael Lynch con una aguda comparación entre las reacciones que suscita usualmente entre los colegas departamentales la política etnometodológica de situar al mismo nivel epistemológico los métodos profesionales de la sociología y los métodos legos de las personas comunes y corrientes - lo que Harold Garfinkel y Harvey Sacks bautizaron como indiferencia etnometodológica ${ }^{38}$ - y las reacciones de las víctimas de uno de los ERs realizados por los estudiantes de Garfinkel, aquel en el que los estudiantes tenían que comportarse dentro del propio hogar familiar como si fuesen invitados: «¿Por qué siempre tienes que andar creando tensiones en nuestra armonía familiar?». «¡No quiero que vuelvas a hacer eso otra vez, y si no eres capaz de tratar a tu madre de forma decente, ya te estás largando de aquí!». «Nosotros no somos cobayas, ¿sabes?»39.

Cuando se trabaja con materiales que son producto de tareas de diseño y producción radicalmente ajenas al trabajo investigador en sí, como sucede con las BCOs capturadas de las emisiones de la televisión comercial, la acusación de "sadismo investigador» debe poder reformularse previamente como denuncia contra el «sadismo televisivo» si es que quiere seguir conservando su quantum inicial de legitimidad. Si bien, paradójicamente, este segundo tipo de denuncia pierde buena parte de su justificación, y por tanto de su razón de ser, cuando, en vez de a los productores del programa, se dirige contra los espectadores/analistas que graban las imágenes emitidas con objeto de reciclarlas para diversos fines, ya sean puramente lúdicos, artísticos o bien, como es el caso, investigadores.

37 Vid. A. Gouldner, La crisis de la sociología occidental [1970], Buenos Aires, Amorrortu, 1973, 361-362; J. Coleman, «Review book of Garfinkel, Studies in Ethnomethodology", American Journal of Sociology, 1968, 33, 126-130.

38 «El objetivo que se proponen los estudios etnometodológicos sobre las estructuras formales [de las acciones prácticas] es describir los análisis [accounts] que de estas estructuras formales hacen los miembros de una sociedad, sea quien sea y se halle donde se halle aquel que lo haga, absteniéndose por tanto de cualquier juicio sobre su adecuación, valor, importancia, necesidad, practicalidad, éxito o consecuencialidad. Denominamos a este procedimiento "indiferencia etnometodológica" " (H. Garfinkel y H. Sacks, «On formal structures of practical actions» [1970], en H. Garfinkel, ed., Ethnomethodological Studies of Work, Cambridge (UK), Cambridge University Press, 1986, 160-193, 166).

39 M. Lynch, Scientific Practice and Ordinary Action, Nueva York, Cambridge University Press, 1993, 2. Y es que, como ha apuntado en otro lugar el propio Lynch: «La indiferencia es un principio a la vez muy difícil y muy peligroso de poner en práctica en la ciencia social contemporánea porque proscribe virtualmente todas las jugadas analíticas mediante las cuales el científico social plantea una distinción programática entre estructuras y creencias superficiales (lo evidente, lo expresado abiertamente) y las realidaldes subyacentes que las causan o las motivan» (M. Lynch y D. Bogen, The Spectacle of History. Speech, Text and Memory in the Iran-contra Hearings, Londres y Durham, Duke University Press, 1996, 264). 
Efectivamente, desde el punto de vista del espectador que no ha participado de la preparación de las bromas, los datos son capturados como «eventos televisivos», esto es, ERs «naturales». Lo cual no quiere decir, por supuesto, que estemos ante un estudio éticamente irreprochable. Ninguna investigación científico-social lo es. Por su parte, aunque perfectamente legítimos y pertinentes, los ejercicios «genéricos» de indignación moral (e.g., las acusaciones de vulgaridad, obscenidad o violencia psicológica) contra los contenidos televisivos no resisten el examen crítico ${ }^{40}$. Tan sólo en casos muy extremos (e.g., violación de derechos fundamentales como el derecho a la intimidad, el derecho al honor o la protección de la infancia), las acusaciones contra los contenidos televisivos resultan, además de legítimas y pertinentes, consecuentes —en un sentido legal material ${ }^{41}$.

En la práctica, los parámetros genéricos de esta específica problemática ética se traducen en una amplia panoplia de elementos materiales concretos: las «palabras mágicas» empleadas por los experimentadores de Garfinkel («sociología», «experimento», «ejercicio para clase», «profesor Garfinkel», «universidad», etc.) son sustituidas, en boca de los actores de las BCOs, por un tipo muy distinto de claves: ante todo «televisión», y por supuesto «broma», pero también «cámara oculta», «programa», «tus amigos», «públicamente», «te va a ver todo Madrid», etc. Si la primera constelación de términos y sus diferentes usos situados nos permite circunscribir empíricamente las fronteras del fenómeno experimento sociológico y delimitarlo respecto de otros objetos culturales (como la «broma inocente» o la «broma pesada»), el segundo conjunto léxico exhibe, en sus detalles sintácticos, semánticos y pragmáticos, un objeto social muy diferente: esa extraña combinación de actividad ordinaria, diseño experimental, adaptación dramatúrgica, montaje fílmico y acto de comunicación pública que llamamos broma de cámara oculta (BCO).

40 Vid. G. Bueno, Telebasura y democracia, Barcelona, Ediciones B, 2002. La conocida tesis del crítico cultural estadounidense Neil Postman (Divertirse hasta morir. El discurso público en la era del «show business», Barcelona, La Tempestad, 2001) de que los medios electrónicos de comunicación de masas, y muy particularmente la televisión, son enemigos objetivos de los principios de comunicación pública que han de regir un mundo democrático tiene poco más de quince años y ya parece haber quedado obsoleta. Con la súbita irrupción en el panorama mediático de los llamados digital media, especialmente Internet, los escritos crítico-culturales intempestivos de Marshall McLuhan sobre la fenomenología política de las tecnologías mecánicas de comunicación pública, aunque escritos veinte años antes que los de Postman, resultan más vigentes. Véase en particular M. McLuhan, Comprender los medios de comunicación. Las extensiones del ser humano [1964], Barcelona, Paidós, 1996.

41 Bueno, Telebasura y democracia, op. cit., 113. En algunos casos extremos de colisión, la broma pesada televisiva puede incluso acabar en los tribunales. «El programa nunca se llegó a emitir pero la MTV [Music TV, un canal de televisión que emite en países de todo el globo] puede ser condenada a pagarlo a precio de oro: una pareja de Washington reclama 10 millones de dólares a la cadena, por invasión de la privacidad y secuelas emocionales por una broma de cámara oculta. La MTV pensó que sería divertido colocar un cadáver mutilado — de pega— en la habitación de un hotel de Las Vegas y observar cómo reaccionaban las víctimas. James y Laurie Ryan se llevaron el susto de su vida, más aún cuando dos supuestos agentes de seguridad del hotel (actores de la cadena musical) les impidieron salir de la habitación hasta que no se descubrió que todo era un montaje. Los productores entraron después, sonrientes. La pareja respondió interponiendo inmediatamente una demanda en un juzgado de California, expediente que acaba de ser trasladado a un tribunal federal en la capital de Estados Unidos. [...] La MTV tiene pendiente otra demanda de dos adolescentes que fueron regadas con excremento humano en otra broma televisiva de la cadena que tampoco se ha programado» (J. del Pino, «Una pareja reclama 10 millones de dólares a la MTV por una broma de cámara oculta», diario El País, 15 de junio de 2002). 
Lejos de constituir una fortaleza inexpugnable a los ataques de los bromistas, la moderna ciencia experimental, dominio por excelencia de la seriedad y la autenticidad, ha sido, desde sus orígenes en el siglo XVII, terreno abonado para la perpetración de todo tipo de travesuras, algunas más inocentes que otras ${ }^{42}$. Dentro del campo de las humanidades y las ciencias sociales, las bromas macabras sólo muy recientemente (vgr., a raíz de la llamada «broma de Sokal», sucedida en 1996) han dejado de ser consideradas un mero objeto de estudio para pasar a convertirse en uno de los elementos constitutivos de la específica forma de vida organizacional de este tipo de actividad investigadora ${ }^{43}$. De suerte que, más allá de su interés estricto dentro del corpus etnometodológico sobre los experimentos de ruptura, el estudio de las secuencias de revelación de las bromas de cámara oculta posee relevancia propia en tanto que ayuda a clarificar las condiciones prácticas bajo las cuales la utopía científica de una práctica social a la vez «seria y formal» se concreta, las más de las veces, en modelos analíticos de juguete, ya que no en desnudas verdades ${ }^{44}$.

\section{APÉNDICE: LOS EXPERIMENTOS DE RUPTURA DE GARFINKEL}

a) Petición de aclaraciones (Garfinkel, «Routine Grounds», 42-44)

\section{CASO 1}

El sujeto, una mujer, le estaba hablando al experimentador, con el que comparte coche para ir a la Universidad, sobre un pinchazo que tuvo mientras iba al trabajo el día anterior.

(S) El otro día pinché.

(E) ¿Qué quieres decir con que pinchaste?

\footnotetext{
42 J. Schnabel, «Puck in the Laboratory: The Construction and Deconstruction of Hoaxlike Deception in Science», Science, Technology and Human Values, 1994, 19, 459-492.

43 A. Sokal y E. Bricmont, Imposturas intelectuales, Barcelona, Paidós, 1999; M. Lynch, «A So-Called "Fraud": Moral Modulations in a Literary Scandal», History of the Human Sciences, 1997, 10, 9-21.

44 L. Wittgenstein, Tractatus Logico-Philoshophicus [1922], Madrid, Alianza, 1973, 6522. «Releer las páginas finales del Tractatus de Wittgenstein. Examinarlas con el propósito siguiente: en el cuerpo del Tractatus Wittgenstein lleva a cabo un análisis naturalista del razonamiento práctico. Al final del Tractatus señala cuáles son los misterios de la razón práctica que propone su análisis naturalista. En sus estudios subsiguientes continúa esta empresa pero tomando ahora como objeto el trabajo de razonamiento práctico, y usando los misterios propuestos por la analítica natural de las prácticas filosóficas como recursos para llevar a cabo varias cosas en sus investigaciones, como encontrar y especificar un tema, separar una figura de su fondo, "delinear un límite" (que debería ser una especie de "dibujo escheriano"), etc.» (Garfinkel, Ethnomethodology's Program, op. cit., 234).
} 
La mujer pareció sorprendida por un momento. Luego respondió con un tono de hostilidad: «¿Qué quieres decir con que qué quiero decir? Un pinchazo es un pinchazo. Eso es lo que quiero decir. Nada especial. Qué pregunta más imbécil».

CASO 2

(S) Hola, Ray. ¿Qué tal está tu chica?

(E) ¿Qué quieres decir con «qué tal está»? ¿Quieres decir física o mentalmente?

(S) Quiero decir que cómo se siente, ¿qué te pasa? (con tono molesto).

(E) Nada. Sólo que me expliques un poco más claramente qué quieres decir.

(S) Déjalo. ¿Cómo va tu solicitud para la facultad de medicina?

(E) ¿Qué quieres decir con «cómo va»?

(S) Venga, ya lo sabes.

(E) No, no lo sé.

(S) ¿Qué te pasa? ¿Estás gilipollas?

CASO 3

El viernes por la noche mi marido y yo estábamos viendo la televisión. Mi marido me dijo que estaba cansado. Le pregunto: ¿Cansado cómo, físicamente, mentalmente o simplemente aburrido?

(S) No sé, sobre todo físicamente, supongo.

(E) ¿Quieres decir que te duelen los músculos o son los huesos?

(S) Eso. No seas tan técnica.

(Un poco después)

(S) En todas estas pelis antiguas salen esas cabeceras de hierro en las camas. 
(E) ¿Qué quieres decir? ¿Quieres decir en todas las películas viejas, o en algunas de ellas, o sólo en las que tú has visto?

(S) ¿Qué coño te pasa? Sabes perfectamente a lo que me refiero.

(E) Me gustaría que fueras más específico.

(S) ¡Sabes lo que te estoy diciendo! ¡Muérete!

\section{CASO 7}

Mi amigo y yo estábamos hablando de una persona cuya actitud dominante nos fastidiaba.

Mi amigo me dijo lo que pensaba.

(S) Estoy harto de él.

(E) ¿Podrías explicarme qué es lo que te pasa para que digas que estás harto de él?

(S) ¿Me estás tomando el pelo? Sabes lo que te estoy diciendo.

(E) Por favor, explícame tu enojo.

(S) (Me escuchaba con mirada confundida) ¿Qué te ha dado? Nosotros nunca hablamos de esa forma, ¿verdad?

b) Huéspedes en el propio hogar (Garfinkel, «Routine Grounds», 45-46)

Los informes elaborados por los estudiantes en este ejercicio solían describir las escenas familiares con un estilo de informe antropológico o etológico. He aquí un extracto de una de las descripciones como muestra:

«Un hombre bajo y corpulento entró en la casa, me besó en la mejilla y me preguntó: “¿Qué tal te ha ido en la universidad?”. Le respondí cortésmente. Fue hacia la cocina, beso a la más joven de las dos mujeres, y dijo hola a la otra. La mujer más joven me preguntó: “¿Qué quieres para cenar, cariño?”. Le respondí: “Nada”. Se encogió de hombros y no dijo nada. La mujer más mayor caminaba por la cocina murmurando. El hombre se lavó las manos, se sentó a la mesa y cogió un papel. Lo leyó 
hasta que las dos mujeres hubieron acabado de poner la comida en la mesa. Los tres se sentaron. Charlaron desenfadadamente sobre los sucesos del día. La mujer más mayor dijo algo en una lengua extranjera que hizo reír a los demás».

En segundo lugar, los estudiantes informaban también de la tremenda dificultad de llevar a cabo el ejercicio.

«Los objetos familiares - las personas, obviamente, pero también los muebles, así como las disposiciones de las habitaciones- se resistían a sus esfuerzos de pensarlos como extraños. Muchos estudiantes descubrieron para su disgusto cómo se desarrollaban los movimientos habituales en su propia casa; cómo se cogía la vajilla, o cómo se abría la puerta y se saludaba a otro miembro. Muchos informaron también que la actitud experimental era difícil de sostener porque hacía turbadoramente visibles a los demás motivaciones hostiles, polémicas o amenazadoras. [...] Buena parte de los informes ofrecían variaciones sobre el tema: "Me alegré cuando pasó la hora y pude volver a mi yo real"».

Conceived as public communication objects, hidden-camera pranks (HCPs) are a documentary variant of ordinary jokes. As opposed to the classic garfinkelian breaching experiments, HCPs also offer a natural form of ethnomethodological experimentation. Presented here are some results of the analysis of a sample of forty-nine HCP revelation sequences (RSs). These small clips (between five and fifty seconds long) allow for the description of a large amount of audiovisual details that are characteristic of the singular, finely coordinated interactional work that actors, hooks and victims of an HPC have to perform in order to «put an end» to an artificially fabricated social situation. My study centres on a series of curious practical relevances of the work of revelation (offer) and awakening (acceptance/rejection) made evident and internally topicalized by the very in vivo social production work of the agents caught up in the HPC situation. What is particularly interesting is the discovery that the academic justifications that make up the revelation sequence of ethnomethodological breaching experiments are replaced here by a singular topic of mundane conversation (the special location of audiovisual recording and broadcasting devices).

Key words: Ethnomethodology, The Sociology of Humor, Videosociology. 